\title{
BROWNFIELDY A INVESTORI V ČESKEJ REPUBLIKE
}

\author{
Zuzana Dvořáková Líšková, Dagmar Škodová Parmová, Petra Pártlová, \\ Petr Dvořák
}

\begin{abstract}
All types of brownfields are created for specific reasons and one of the main resources is the state economy restructuring as well as restructuring of the economy of particular regions The objective of this contribution was to apply the German model evaluation of brownfields for the conditions of Czech Republic, based on which we would be able to perform evaluation of brownfields from the point of view of a investor. Altogether, 280 brownfields were assessed. The model applied in Czech republic was based on 8 parameters. The interpretation of parameters was modified according to the local specifics, with respect to data availability. From the point of view of an investor, the most brownfields (111) are well located, easy to reach, without regulations set by the area planning documentation and available workforce.
\end{abstract}

Keywords: brownfields, financing, risk, redevelopment

\section{Úvod}

Regenerácia brownfieldov má svoje nezanedbatel'né ekonomické aspekty, predovšetkým hl'adanie finančných prostriedkov. Vo väčšine prípadov dochádza ku kombinácii financií z verejných rozpočtov, prostriedkov zo štrukturálnych fondov EÚ a prostriedkov $\mathrm{z}$ investícií súkromného sektora. $\mathrm{Na}$ získanie súkromných investícií pre konkrétny pozemok je nevyhnutné potenciálnych investorov motivovat', pochopit' ich záujmy a možnosti a reagovat' na ne úspešnou marketingovou stratégiou miest a obcí. Vhodné investície na transformáciu brownfieldov je nutné určitými nástrojmi podporovat', investície smerujúce $\mathrm{k}$ zaberaniu nových greenfieldov je naopak nevyhnutné usmerňovat' a limitovat'.

Existencia brownfieldov $\mathrm{v}$ obci spôsobuje pokles jej ekonomickej atraktivity, na čom tratia i d'alší vlastníci pozemkov a podnikov a tiež miestni obyvatelia. Najmä v štrukturálne postihnutých regiónoch môže úspešný projekt znamenat' významné oživenie a naštartovanie celej lokality. Počiatočná investícia sa potom zhodnocuje tvorbou nových pracovných miest, rozvojom podnikania a obchodu. Podniky vytvárajú ekonomickú štruktúru oblasti a majú tiež vplyv na sociálno-ekonomické prostredí (Rizzo et al., 2015). Nie všetky pozemky, ktoré sú brownfieldy, sú vhodné pre priemyselnú výrobu, ale aj ich regenerácia na plochu zelene má pozitívny ekonomický efekt. V záujme verejného sektora a obyvatel'ov je vždy príprava a realizácia projektu reálne a objektívne pripraveného, ktorého 
hlavným ciel'om nie je generovat' iba zisk. Ale ani verejný sektor by sa nemal snažit' realizovat' projekty neziskové, pretože podhodnocovaním následných prevádzkových a udržiavacích nákladov, ktoré žiadajú objemy prostriedkov a nie sú pokryté z projektu, vzniká reálne nebezpečenstvo d’alších problémov.

\section{Brownfieldy na ekonomickom trhu}

Brownfieldy zdiel'ajú s pozemkami na tzv. Zelených lúkach (zastavitel’né územia) totožný realitný trh. Predpokladat', že brownfieldy si vytvoria nejaký paralelný realitný trh, nie je ani reálne ani efektívne, aj ked', a to je pozitívne, už existujú špecialisti na obchodovanie $\mathrm{s}$ týmito plochami. Niektoré brownfieldy vd'aka svojej dobrej strategickej polohe sú pre investorov natol'ko zaujímavé, že realizujú svoju výstavbu na plochách brownfieldov. Projekty na Brownfield sú zvyčajne drahšie, zložitejšie, časovo náročnejšie a teda d'aleko riskantnejšie pre svojho investora. To st’ažuje hladanie investora a často je potrebné ponúknut' nejaký benefit, ktorý by na Greenfieldoch nebol možný (Bartke, Schwarze, 2015).

Projekty na brownfield môžu ale na trhu nehnutel'ností uspiet' originalitou. Takéto projekty však vyžadujú vel'mi skúsených investorov a finančné inštitúcie. Vyžadujú ale aj komplexný pohl'ad povolaných úradníkov, ktorí zohl'adnia kvalitu a histórii miesta. V posledných desiatich, pätnástich rokoch máme možnost' vidiet' viacero nesmierne zaujímavých konverzií, ktoré reflektovali originalitu miesta. Pri bližšom skúmaní môžeme zistit', že predovšetkým na začiatku sa mnohé z nich nevyhli chybám a podcenenam súvisiacich s nedostatočným pochopením problému opustených plôch a areálov (Martinat, 2018).

Oceňovanie nehnutel'ností je samostatný odbor majúci vel'ký rad svojich pravidiel a povinností. V Českej republike sa využívajú všeobecne tri metódy oceňovania i pre plochy a budovy brownfieldov: nákladová metóda; porovnávacia metóda; metóda obvyklej ceny.

Podla nákladovej metódy sa cena určuje na základe výdavkov vynaložených $\mathrm{v}$ minulosti na obstaranie určitej nehnutel'nosti. V priebehu existencie tejto nehnutel'nosti vd’aka odpisom a opravám táto cena klesá.

Porovnávacia metóda vychádza z ceny konkrétnej nehnutel'nosti podl'a aktuálnej cenovej situácie na trhu danej oblasti. Z predajných cien porovnatel'ných nehnutel'ností sa prirovnáva aj pravdepodobná výška ceny posudzovanej nehnutel'nosti. Prístup založený na porovnávaní je kl'účový pri odhade trhovej hodnoty.

Výnosový prístup je založený na prognóze o budúcom úžitku a vel'kosti výnosu z nehnutel'nosti, ale aj jej spol'ahlivosti, stabilite, zároveň neprihliada na potrebné vynaložené náklady v budúcnosti (Ort, 2013). 


\section{Riziká a zodpovednost' pri regenerácii brownfieldov}

Regenerácia brownfieldov so sebou nesie mnoho rizík, ktoré sú hlavnou prekážkou rozvoja týchto území, demotivujú potenciálnych investorov a bránia tak prílivu ako domácich, tak i zahraničných investícií. Okrem bežných podnikatel'ských rizík, ktoré sprevádzajú každý projekt, tu musí každý potenciálny investor čelit' rizikám naviac, akými sú vyššia finančná náročnost', odstraňovanie ekologickej zát'aže, dlhší časový horizont projektu, pomalší návratnost' investícií, zložitá koordinácia a zdíhavé administratívne postupy (Turečková, 2018). Z úplne zrejmých dôvodov súkromný sektor odmieta niest' zodpovednost' za tieto riziká sám, preto je pri projektoch regenerácie brownfieldov nevyhnutné ich zdiel'anie viacerými partnermi. Zároveň však týmto zdiel'aním hrozí roztrieštenost' či oslabenia rizík a zodpovednosti. Ďalšou otázkou potom zostáva, či pri zdiel'aní rizík a zodpovednosti všetci zúčastnení partneri zdiel'ajú tiež konečný zisk.

Neoddelitel'nou súčast’ou každého projektu, nielen regenerácie brownfieldov, sú riziká, ktoré sa objavujú v rôznych fázach projektu. Jedná sa o riziká: plánovacie, projekčné, stavebno technické, prevádzky a údržby, marketingové a finančné.

Pre každý projekt tiež existujú riziká týkajúce sa spolupráce jednotlivých aktérov, s mierou spol'ahlivosti všetkých dodávatel'ov. Pri každom projekte je nevyhnutné vypracovat' tzv. Rizikovú analýzu.

Táto analýza zahŕňa: identifikáciu jednotlivých rizík, posúdenie ich závažnosti, zváženie početnosti ich výskytu, zistenie celkového ohrozenia projektu.

Dôležitým krokom je tiež alokácia rizík, čiže prisúdenie určitých rizík určitým aktérom. Alokácia rizík by nemala znamenat' len snahu zbavit' sa zodpovednosti, ale mala by brat' do úvahy schopnost' jednotlivých aktérov riadit' riziká a niest' za pridelený úsek zodpovednost'. Vybraní aktéri by tiež mali disponovat' finančnými i inými prostriedkami na odstránenie prípadných následkov. Riziká by teda pri projektoch mala niest' tá strana, ktorá má najlepšie predpoklady k ich efektívnemu zvládnutie (Bardos et al., 2016).

Pri PPP - public private partnership niekedy môže dochádzat' $\mathrm{k}$ snahe presúvat' určité investičné a prevádzkové riziká na zástupcov súkromného sektora, čo na jednej strane čiastočne zbavuje verejný sektor zodpovednosti, na druhej strane však tiež znamená istú stratu kontroly nad projektom. V ideálnom prípade by mali byt' zmluvné podmienky partnerstva nastavené tak, aby boli všetci partneri finančne či inak zainteresovaní na projekte a teda, aby ohrozenie projektu znamenalo prípadnú stratu pre všetkých zúčastnených (Lange, McNeil, 2004).

Proti rizikám sa môžu aktéri bránit' uzatváraním rôznych druhov poistenia, napr.: poistenie úverov, ktoré garantuje splácanie úverov pri momentálnej neschopnosti splátok zo strany majitel’a úveru; poistenie proti rizikám plynúcim z ekologických zát'aží. Zabezpečuje investora proti možnosti, že sa v budúcnosti objavia d'alšie 
kontaminácie, ktorá nebola pri predaji známa alebo dôjde k sprísneniu legislatívy, čo sa týka limitu ekologického znečistenia.

Poistenie tiež môže chránit' investora pred žalobami zo strany tretích osôb, ktoré požadujú odškodnenie za poškodenie zdravia vzniknuté v dôsledku kontaminácie.

\section{Finančná zát’až regenerácie brownfieldov}

Okrem ekologickej zát'aže predstavuje značné riziko pre investora aj finančná náročnost' projektu regenerácie brownfieldov, a to najmä čo sa týka kalkulácie zisku investičné akcie. Úspech projektu je odhadovaný v marketingových štúdiách, avšak tie nepredstavujú dostatočné záruky budúceho dopytu.

Partneri musia navyše počítat' s neistotou týkajúcou sa sa vývoja miestneho trhu. Neúspešný projekt predstavuje pre trhovo orientovaný súkromný sektor finančnú stratu aj stratu prestíže.

Verejný sektor by mal preto vol'be strategického partnera venovat' osobitnú pozornost'. Mal by posudzovat' celkovú dôveryhodnost' súkromného investora, požadovat' dôkaz solventnosti a schopnosti financovat' výstavbu, ukážky už realizovaných stavieb a zoznam hlavných subdodávatel'ov (National Brownfields Regeneration Strategy, 2008).

Všetky projekty brownfieldov musia byt' vzhl'adom na svoju náročnosti financované formou úveru, čo $\mathrm{v}$ tomto prípade predstavuje riziko predovšetkým vzhl'adom $\mathrm{k}$ pomalej návratnosti investícií, ktorá môže byt' ešte predížená finančným postihom za meškanie dokončenie projektu, čo je jedno z najbežnejších rizík výstavby.

Bankový úver musí byt' vždy istým spôsobom garantovaný, aby ho banka bola ochotná odsúhlasit'. Niekedy existujú medzi oboma súkromnými subjektmi zvláštne partnerské vzt'ahy. Banky môžu napríklad vlastnit' dcérsku spoločnost' investujúcu na trhu s nehnutel'nost'ami. Tieto súkromné subjekty potom l'ahšie získajú potrebný úver, pretože investorom projektu je vlastne banka sama. Takí silní investori samozrejme vzbudzujú dôveru u d'alších zúčastnených aktérov (Burinskiene et al., 2017). Finančný ústav si vždy kladie určité garančné podmienky, väčšinou požaduje ručenie úveru nehnutel'ným majetkom. Jednou z takýchto podmienok môže byt' napríklad $100 \%$ vlastníctvo pozemku investorom, ktoré vylučuje participáciu d’alších aktérov, s ktorými príslušná banka nemá uzatvorený žiadny zmluvný vzt’ah. Nehnutel'nost', stojaca na pozemku iného vlastníka, má pre banku pochopitel’ne nižšiu hodnotu. V prípade neúspešného projektu potom banka získa daný pozemok. V Česku a na Slovensku je táto podmienka často komplikovaná nevyjasnenými vlastníckymi vzt'ahmi na území s brownfieldami, čo môže byt' dôvodom neposkytnutia úveru. V prípade regenerácie brownfieldov sa navyše často nedá pozemkom ručit', pretože má až na výnimky skôr zápornú hodnotu. Ďalším typom záruky je zmluva o budúcej zmluve záloha 
na nehnutel'nost', ktorá bude niekedy na pozemku postavená, pretože pozemok, na ktorom by bola postavená nehnutel'nost' vlastnená cudzou osobou, by bol nepredajný (Alexandrescu et al., 2014). Garancia nehnutel'ným majetkom sú špecifické pre developerské firmy, ktoré žiadajú o úver na výstavbu nehnutel'nosti určenej zvyčajne $\mathrm{k}$ okamžitému predaju po dokončení a priamo konkrétnu nehnutel'nost' vlastní len po vel'mi krátku dobu. V niektorých prípadoch môže byt' pre banku zárukou už podpísaný kontrakt o budúcom predaji alebo prenájme nehnutel'nosti. Škála rizík je pomerne široká a ich dopady ovplyvňujú rôzne subjekty rôznym spôsobom (Limasset et al., 2018).

Bankový úver súkromného subjektu tiež môže byt' zaručený zo strany štátu. Jedná sa o projekty "joint venture", na ktorých realizácii spolupracuje verejný a súkromný sektor. $\mathrm{V}$ týchto prípadoch napríklad obec ručí obecným majetkom, napríklad dotknutým pozemkom, alebo inými nehnutel'nost’ami, ktoré vlastní. Tu však existuje pomerne vel'ké riziko zástavy $\mathrm{z}$ dôvodu neúspechu investičného zámeru, podobne ako $\mathrm{v}$ prípade, ak je projekt financovaný $\mathrm{z}$ úveru poskytnutého priamo obci. Nebezpečenstvo pre verejný sektor predstavujú predovšetkým úvery, podpísané miestnymi samosprávami. Menšie obce majú značne obmedzený verejný rozpočet a v prípade neúspešného projektu nie sú schopné úver splácat', či garantovat' (Klusáček et al., 2018). Bankovou zárukou môžu byt' v týchto prípadoch hodnotné nehnutel'nosti v majetku obce, napríklad historické budovy na námestí a pod. Prevod týchto nehnutel'ností do vlastníctva súkromného subjektu banky, nie je samozrejme v záujme obce. $\mathrm{V}$ takýchto prípadoch je uhradenie úveru zodpovednost'ou regionálnej samosprávy alebo štátnej správy. Všeobecne sa však stat' snaží skôr presunút' zodpovednost' a riziká na súkromných partnerov a nie je v jeho záujme žiadat' o bankové úvery alebo ručit svojím majetkom. Riadenie finančného alebo iného rizika sa realizuje znížením rizika, znížením strát alebo ich kombináciou. Viacero zistení prinášame vo výsledkoch.

\section{Metodika}

K spracovaniu údajov o lokalitách brownfields v Českej republike $\mathrm{v}$ jednotlivých krajoch bolo nutné získat' povolenie majitel'a prípadne všetkých spoluvlastníkov. Podarilo sa získat súhlas u 20 bronfieldov v každom kraji, tak aby bola vzorka reprezentatívna (Národná databáze brownfieldů, 2018). U týchto lokalít bola vykonaná ich evaluácia, t. j. bodové hodnotenie.

Použitá metodika vychádza zo štúdie nemeckého Ministerstva životného prostredia (Clarinet, 2002), ktorá doteraz priniesla najkomplexnejšie posúdenie brownfieldov. Pôvodná metodika je zameraná na aplikáciu modelu založenom na bodovom hodnotení parametrov, ktoré sú radené podl'a; potenciálu miesta $z$ hl'adiska obce, potenciálu úžitku z hl'adiska investora a zmeny hodnoty miesta $\mathrm{z}$ pohl'adu verejného záujmu. Pre náš článok sme vybrali potenciál úžitku z hl'adiska investora s celkom 8 parametrami s bodovým rozpatím na škále 0 (najhoršie) až 4 
body (najlepšie). Interpretácia parametrov bola upravená podl’a miestnych špecifík Českej republiky, vzhl'adom na dostupnost' dát.

Pre hodnotenie boli využité podkladové dáta z CzechInvestu a vlastné zistenia $\mathrm{z}$ terénneho prieskumu.

\section{Parametry pre potenciál miesta z hl'adiska investora}

- Regulativa podl'a územno plánovacej dokumentácie

- Ručenia za závazky

- Možnosti využitia dotácí́

- Atraktivita

- Dostupnost pracovných síl

- Prítomnost' silných odvetví a ekonomických subjektov

- Infraštruktúrne zabezpečenie

- Další výhody (daňové úl'avy...)

\section{Spolu 8 parametrov}

Hodnotenie $0-4$ body

Maximálný počet bodov +32

Minimální počet bodov +4

\begin{tabular}{l|l} 
VYSOKÝ & $24-32$ bodov \\
\hline ŠPECIFICKÝ & $16-23$ bodov \\
\hline MINIMÁLNY & $4-15$ bodov
\end{tabular}

Výsledky

Z pohl'adu investora je dôležitá strategická poloha miesta. Ak lokalita nemá výhodu strategickej polohy, je malá šanca na regeneráciu brownfields, a to je predovšetkým v malých obciach a ich extravilánoch. Investori majú väčší záujem o také lokality, ktoré sú nejakým spôsobom atraktívne či známe. Aplikáciou modelu na sledovanom vzorku 280 brownfieldov bolo zistené, že 111 lokalít má z pohl'adu investora vysoký potenciál. Z hl'adiska krajov je najlepšia situácia - brownfieldy $\mathrm{s}$ vysokým potenciálom $\mathrm{v}$ kraji Stredočeskom, Jihomoravskom a Vysočine. Lokality majú aj dobrú dopravnú dostupnost', infraštruktúrne zabezpečenie a sú atraktívne pre investorov (tab. 1). 81 brownfieldov má špecifický potenciál, jedná sa predovšetkým o Prahu, Jihočeský kraj, Královohradecký kraj. Všeobecne možno povedat', že technická infraštruktúra týchto lokalít je v uspokojivom stave. Budúci investor nemusí vynaložit' svoje finančné zdroje do vybudovania nových inžinierskych sietí. Nutná je len modernizácia už existujúcej technickej infraštruktúry. Naopak minimálny potenciál, kde brownfieldy dosiahli menej ako 15 bodov sa nachádzajú predovšetkým v Ústeckom a Moravskosliezkom kraji. 
Tab. 1: Evaluácia brownfieldov v Českej republice

Table 1: Evalutation of brownfields in Czech republic

\begin{tabular}{|c|c|c|c|c|}
\hline kraj & $\begin{array}{c}\text { Vysoký } \\
\text { potenciál } \\
\text { (počet) }\end{array}$ & $\begin{array}{l}\text { Špecifický } \\
\text { potenciál } \\
\text { (počet) }\end{array}$ & $\begin{array}{l}\text { Minimálny } \\
\text { potenciál } \\
\text { (počet) }\end{array}$ & $\begin{array}{l}\text { Celkový počet } \\
\text { hodnotených } \\
\text { brownfieldov }\end{array}$ \\
\hline $\begin{array}{l}\text { Hlavní město } \\
\text { Praha }\end{array}$ & 9 & 9 & 2 & 20 \\
\hline Středočeský & 13 & 4 & 3 & 20 \\
\hline Jihočeský & 7 & 8 & 5 & 20 \\
\hline Plzeňský & 8 & 4 & 8 & 20 \\
\hline Karlovarský & 5 & 8 & 7 & 20 \\
\hline Ústecký & 2 & 5 & 13 & 20 \\
\hline Liberecký & 7 & 8 & 5 & 20 \\
\hline Královéhr. & 10 & 6 & 4 & 20 \\
\hline Pardubický & 8 & 4 & 8 & 20 \\
\hline Vysočina & 11 & 5 & 4 & 20 \\
\hline Jihomoravský & 12 & 5 & 3 & 20 \\
\hline Olomoucký & 9 & 5 & 6 & 20 \\
\hline Zlínský & 6 & 6 & 8 & 20 \\
\hline Moravskosl. & 4 & 4 & 12 & 20 \\
\hline spolu & 111 & 81 & 88 & 280 \\
\hline
\end{tabular}

\section{Zdroj: vlastné spracovanie}

Ďalšími zistením je existencia možností prerozdelenia rizík. Napríklad riziká investora tiež môžu byt' prenášané alebo prerozdelené na:

- poistníka,

- dodávatel'ov a subdodávatel'ov,

- developera,

- schval'ovacie a regulačné orgány,

- tím profesionálnych poradcov a konzultantov,

- verejnost' a PR apod.

Nasledujúca tab. 2 popisuje rôzne riziká dotknutých strán zainteresovaných na rozvoji brownfieldov. 
Tab. 2: Riziká zainteresovaných subjektov pri rozvoji brownfieldov

Table 2: Risks of stakeholders in brownfield development

\begin{tabular}{|c|c|c|c|c|c|}
\hline \multirow{2}{*}{ Subjekt } & \multicolumn{5}{|c|}{ Typ rizika } \\
\cline { 2 - 6 } & právne & fin. & tech. & zdrav. & iné \\
\hline $\begin{array}{c}\text { investor, finančná } \\
\text { inštitúcia }\end{array}$ & $\mathrm{X}$ & $\mathrm{X}$ & - & - & - \\
\hline developer & $\mathrm{X}$ & $\mathrm{X}$ & $\mathrm{X}$ & $\mathrm{X}$ & $\mathrm{X}$ \\
\hline právnik & $\mathrm{X}$ & $\mathrm{X}$ & - & - & - \\
\hline realitný konzultant & $\mathrm{X}$ & $\mathrm{X}$ & $\mathrm{X}$ & - & $\mathrm{X}$ \\
\hline $\begin{array}{c}\text { konzultant } \\
\text { životného } \\
\text { prostredia }\end{array}$ & $\mathrm{X}$ & $\mathrm{X}$ & $\mathrm{X}$ & $\mathrm{X}$ & $\mathrm{X}$ \\
\hline $\begin{array}{c}\text { konzultant, } \\
\text { projektant }\end{array}$ & $\mathrm{X}$ & $\mathrm{X}$ & $\mathrm{X}$ & $\mathrm{X}$ & - \\
\hline $\begin{array}{c}\text { vejná správa, } \\
\text { samospráva }\end{array}$ & $\mathrm{X}$ & $\mathrm{X}$ & $\mathrm{X}$ & $\mathrm{X}$ & $\mathrm{X}$ \\
\hline verejnost & - & - & - & $\mathrm{X}$ & $\mathrm{X}$ \\
\hline
\end{tabular}

Zdroj: vlastné spracovanie

Rôzne subjekty sa s investorom o riziká môžu delit'. Vhodné prerozdelenie a prenesenie rizík je významné najmä pri regenerácii brownfieldov realizovaných formou Partnerstvo verejného a súkromného sektora. Nasledujúca tab. 3 ukazuje možné spôsoby zmiernenie rizík pre vybrané aktivity.

Tab. 3: Možné spôsoby zmiernenia rizika

Table 3: Possible ways to mitigate risk

\begin{tabular}{|c|c|c|c|c|c|}
\hline \multirow{2}{*}{ Typ rizika } & \multicolumn{5}{|c|}{ Typy možných zmiernení rizik } \\
\cline { 2 - 6 } & Poistenie & $\begin{array}{c}\text { Zml. } \\
\text { záruky }\end{array}$ & $\begin{array}{c}\text { Pokuty, } \\
\text { penále }\end{array}$ & $\begin{array}{c}\text { Dod. } \\
\text { záruky }\end{array}$ & Iné \\
\hline Nákup brownfieldu & - & $\mathrm{X}$ & $\mathrm{X}$ & $\mathrm{X}$ & $\mathrm{X}$ \\
\hline Finančná dostupnost & - & - & - & $\mathrm{X}$ & $\mathrm{X}$ \\
\hline $\begin{array}{c}\text { Právna zodpovednost' } \\
\text { developera }\end{array}$ & $\mathrm{X}$ & $\mathrm{X}$ & $\mathrm{X}$ & - & $\mathrm{X}$ \\
\hline $\begin{array}{c}\text { Právna zodpoovednost' } \\
\text { konzultanta }\end{array}$ & $\mathrm{X}$ & $\mathrm{X}$ & $\mathrm{X}$ & - & $\mathrm{X}$ \\
\hline $\begin{array}{c}\text { Zodpovednost' realit. } \\
\text { kancelárí́ }\end{array}$ & $\mathrm{X}$ & - & - & - & $\mathrm{X}$ \\
\hline $\begin{array}{c}\text { Zodpovednost' } \\
\text { dodávatel'a }\end{array}$ & $\mathrm{X}$ & $\mathrm{X}$ & $\mathrm{X}$ & $\mathrm{X}$ & $\mathrm{X}$ \\
\hline
\end{tabular}




\begin{tabular}{|c|c|c|c|c|c|}
\hline $\begin{array}{c}\text { Zodpovednost' } \\
\text { developera za projekt }\end{array}$ & $\mathrm{X}$ & $\mathrm{X}$ & $\mathrm{X}$ & $\mathrm{X}$ & $\mathrm{X}$ \\
\hline Enviro. zodpovednost & & $\mathrm{X}$ & $\mathrm{X}$ & $\mathrm{X}$ & $\mathrm{X}$ \\
\hline $\begin{array}{c}\text { Zodpovednost' tretích } \\
\text { strán }\end{array}$ & $\mathrm{X}$ & $\mathrm{X}$ & - & - & - \\
\hline $\begin{array}{c}\text { Riziká plánovacích } \\
\text { procesov }\end{array}$ & - & $\mathrm{X}$ & - & - & $\mathrm{X}$ \\
\hline $\begin{array}{c}\text { Riziká protestov } \\
\text { verejnosti }\end{array}$ & - & - & - & - & $\mathrm{X}$ \\
\hline
\end{tabular}

Zdroj: vlastné spracovanie

\section{Záver}

Záujem potenciálnych investorov o brownfieldy zvyšuje absencia limitov, ktoré by obmedzovali prevedenia podnikatel'ského zámeru.

Z pohl'adu investora je dôležitá strategická poloha miesta. Ak lokalita nemá výhodu strategickej polohy je malá šanca na regeneráciu brownfieldov, a to predovšetkým v malých obciach a ich extravilánoch. Investori majú väčší záujem o také lokality, ktoré sú nejakým spôsobom atraktívne či známe. Preto lokality zo sledovanej vzorky, ktoré dosiahli vysokého potenciálu sú lokalizované väčšinou v intraviláne väčších miest.

Aj na rastúcom trhu majú brownfieldy plno nevýhod. Investori sa o ne začínajú zaujímat' až vtedy, ked' je trh plne rozbehnutý a prestávajú sa o brownfieldy zaujímat', ked' trh začne klesat'. Tiež príprava brownfieldových projektov trvá dlhšie, je technicky zložitejší a potrebuje viac konzultantov než u bežných projektov. Preto sú projekty na brownfieldy drahšie. Ked’že sa stav už existujúcich nehnutel'ností nedá na $100 \%$ odhadnút', regenerácia so sebou vždy nesie d'alšie riziká. To potom môže spôsobit' predíženie doby realizácie a nárast rozpočtovaných nákladov. Spôsobuje to tiež, že banky požadujú vyššie úrokové sadzby a developeri požadujú navýšenie svojich ziskov, aby pokryli svoje riziká. Banky tiež požadujú po developeroch vyššiu sumu ich vlastného kapitálu a vyšší podiel zmluvne zaistených budúcich predprenájmov. To všetko robí financovania regenerácie brownfieldov nielen drahšie, ale aj t’ažšie.

\section{Pod'akovanie}

Príspevok vznikol na základe podpory projektov: Economic aspects of regeneration of brownfields in South-Bohemian region- P402/10/P344 „CENAKVA“ (No. CZ.1.05/2.1.00/01.0024); ,CENAKVA II“ (No. LO1205 under the NPU I program). 


\section{Literatúra}

ALEXANDRESCU, F. - MARTINAT, S. - KLUSACEK, P. - BARTKE, S. 2014. The path from passivity toward entrepreneurship: public sector actors in brownfield regeneration processes in Central and Eastern Europe. In Organization and Environment. vol. 27, no. 2, pp. 181-201.

BARDOS, R. P. - JONES, S. - STEPHENSON, I. - MENGER, P. - BEUMER, V. - NEONATO, F. et al. 2016. Optimising value from the soft re-use of brownfield sites. In Science of the Total Environment. vol. 563, pp. 769-782.

BARTKE, S. - SCHWARZE, R. 2015. No perfect tools: Trade-offs of sustainability principles and user requirements in designing support tools for land-use decisions between greenfields and brownfields. In Journal of Environmental Management. vol. 153, pp. 11-24.

BURINSKIENE, M. - BIELINSKAS, V. - PODVIEZKO, A. - GURSKIENE, V. - MALIENE, V. 2017. Evaluating the significance of criteria contributing to decision-making on brownfield land redevelopment strategies in urban areas. In Sustainability. vol. 9, no. 5, pp. 148-164.

CLARINET. 2002. Brownfields and Redevelopment of Urban Areas. Vienna: Federal Environmental Agency Ltd: Umweltbundesamt GmbH. 117. [online 2018-01-15]. Dostupné na internete: http://www.umweltbundesamt.at/ fileadmin/site/umweltthemen/altlasten/clarinet/brownfields.pdf

KLUSACEK, P. - ALEXANDRESCU, F. - OSMAN, R. - MALY, J. - KUNC, J. - DVORAK, P. - FRANTAL, B. - HAVLICEK, M. - KREJCI, T. MARTINAT, S. 2018. Good governance as a strategic choice in brownfield regeneration: Regional dynamics from the Czech Republic. In Land Use Policy. vol. 73, pp. 29-39.

LANGE, D. A. - McNEIL, S. 2004. Brownfield development: Tools for stewardship. In Journal of Urban Planning and Development. vol. 130, pp. 109-116.

LIMASSET, E. - PIZZOL, L. - MERLY, C. - GATCHETT, A. M. - LE GUERN, C. - MARTINAT, S. - KLUSACEK, P. - BARTKE, S. 2018. Points of attention in designing tools for regional brownfield prioritization. In Science of the Total Environment. vol. 622, pp. 997-1008.

MARTINAT, S. - NAVRATIL, J. - HOLLANDER, J. B. - TROJAN, J. KLAPKA, P. - KLUSACEK, P. - KALOK, D. 2018. Re-reuse of regenerated brownfields: Lessons from an Eastern European post-industrial city. In Journal of Cleaner Production. vol. 188, pp. 536-545.

NATIONAL BROWNFIELDS REGENERATION STRATEGY. 2008. Ministry of Industry and Business: Prague. [online 2018-04-24]. Available online: http://www.cityinvestczech.cz/data/files/strategie-regenerace-vlada-1079.pdf

NÁRODNÍ DATABÁZE BROWNFIELDU. 2018. [online 2018-04-20]. Available online: https://brownfieldy.czechinvest.org/Aplikace/bfpublic.nsf/bfs.xsp 
ORT, P. 2013. Oceňování nemovitostí - moderní metody a př́istupy. Praha: Leges Praktik. ISBN 978-80-87576-77-9.

RIZZO, E. - PESCE, M. - PIZZOL, L. - ALEXANDRESCU, F. M. GIUBILATO, E. - CRITTO, A. - BARTKE, S. 2015. Brownfield regeneration in Europe: Identifying stakeholder perceptions, concerns, attitudes and information needs. In Land Use Policy. vol. 48, pp. 437-453.

TUREČKOVÁ, K. 2018. The Role of Public Administration and EU in the Context of Brownfields. In Proceedings of the 4th International Conference on European Integration 2018, Ostrava, Czech Republic, 17-18 May 2018, pp. 1522-1530.

\section{BROWNFIELDS AND INVESTORS IN THE CZECH REPUBLIC}

\section{Summary}

Brownfield has become a worldwide recognized term that refers to "any land or premises which has previously been used or developed and is not currently fully in use, although it may be partially occupied or utilized (...) may be vacant, derelict or contaminated (...) therefore not necessarily available for immediate use without intervention" (Alker et al., 2000). Some countries, for example USA, United Kingdom, France and West Germany, have long-term experience with the problems of brownfields, which had emerged already during the 1970s as a result of massively declining mining, heavy industries and textiles.

Brownfields rehabilitation is currently a complicated problem in the Czech and Republic. Investor distrust concerning the brownfi elds potential is a great negative in comparison with "greenfi eld" construction areas. Th is is implied by the unequal market environment conditions when the investors are discouraged by high investment costs of the restoration or decontamination of the brownfi elds, which are frequently connected with the need for thorough environmental cleanup and removal of unsuitable structures. Revitalization of a large number of location is still hindered by environmental hazards, investment intensity and frequently also by complicated and unexplained property rights. Municipalities will be left with a number of problem sites with many ecological and other burdens depressing the value of real estate in their neighbourhoods. For the sake of future, when massive public support for regeneration cannot be expected, it is desirable that system measures are put in place that would assure more effective support to brownfield regeneration, for example in the sphere of urban planning and development as well as in the fiscal sphere. 
RNDr. Zuzana Dvořáková-Líšková, Ph.D.

doc. Dr. Dagmar Škodová Parmová

Katedra regionálního managmentu

Ekonomická fakulta

Jihočeská univerzita v Českých Budějovicích

Studentská 13, 37005 České Budějovice

E-mail: zuli@ef.jcu.cz,parmova@ef.jcu.cz

Ing. Petra Pártlová, Ph.D.

Ústav podnikové strategie

Vysoká škola technická a ekonomická

Okružní 517/10, 37001 České Budějovice

E-mail: vachalovap@seznam.cz

Ing. Petr Dvořák, Ph.D.

Ústav aquakultúry a ochrany vod

Fakulta rybářství a ochrany vod

Jihočeská univerzita v Českých Budějovicích

Na Sádkách 1780, 37005 České Budějovice

E-mail: dvorakp@frov.jcu.cz 